\title{
Analysis of Cognitive Skills in History Textbook (Spain-England-Portugal)
}

\author{
Cosme J. Gómez ${ }^{1}$, Glória Solé ${ }^{2}$, Pedro Miralles ${ }^{1 *}$ and Raquel Sánchez ${ }^{1}$ \\ ${ }^{1}$ CEIR Campus Mare Nostrum, University of Murcia, Murcia, Spain, ${ }^{2}$ University of Minho, Braga, Portugal
}

OPEN ACCESS

Edited by:

Jesus de la Fuente,

University of Navarra, Spain

Reviewed by:

Evangelia Karagiannopoulou, University of loannina, Greece

Joana R. Rato,

Universidade Católica Portuguesa,

Portugal

${ }^{*}$ Correspondence:

Pedro Miralles

pedromir@um.es

Specialty section:

This article was submitted to Educational Psychology, a section of the journal

Frontiers in Psychology

Received: 17 December 2019

Accepted: 14 November 2020

Published: 30 November 2020

Citation:

Gómez CJ, Solé G, Miralles P and

Sánchez R (2020) Analysis of Cognitive Skills in History Textbook (Spain-England-Portugal).

Front. Psychol. 11:521115. doi: 10.3389/fpsyg.2020.521115
The main objective of this article is to analyze the cognitive level of the activities in History textbooks in Spain, England, and Portugal in the transition stage from Primary to Secondary Education (11-13 years), according to the country of origin, typology, and the concepts and disciplinary contents included. The design of this research is quantitative, descriptive, and cross-sectional. The non-probabilistic sample consists of 6,561 activities contained in 27 school textbooks from Spain, England, and Portugal. Descriptive and contrast analyses have been carried out using parametric tests. The results indicate that textbooks from Spain and Portugal mainly include activities situated between a basic and intermediate cognitive level while in England, the cognitive level of activities is medium or high. The ANOVA and Tukey $B$ tests show significant differences between the cognitive level required in the activities and the typology of exercises, the concepts, and historical contents worked on. The activities with higher cognitive level correspond to those of creation and essays, the exercises that work on empathy and historical relevance, and that contain activities of social and economic history. In contrast, the activities with the lowest cognitive level are short questions and objective tests, those that work on first-order concepts (data and concrete facts), and those on the History of Art. The conclusion is that there is a need for a balanced presence of first-order content and historical thinking skills, the application in the classroom of a more active student-centered methodology, and the teachers' conception of history teaching that prioritizes historical skills.

Keywords: history education, textbooks, historical thinking, cognitive skills, epistemology

\section{INTRODUCTION}

The textbook is a cultural, academic, commercial, and ideological product. The purpose of textbooks has always been to bring together the set of fundamental truths that every student must know well and believe; facts, knowledge, and beliefs that are established as closed, immutable, and unquestionable (Viñao, 2003). Carbone (2003) considers that school books are cultural works with their own identity, which must be analyzed from a multidisciplinary point of view. Furthermore, textbooks constitute relevant teaching material that facilitates the learning process and can improve two-way participation between students and teachers. Thus, structured access to this type of attractive material makes lessons more interesting and entertaining (Pavón et al., 2014).

Textbooks for the Spanish curriculum, which is mainly regressive in nature, contain an extension of the curriculum contents so that these reach the classroom with almost no 
modification-an issue that deserves more attention than it currently receives. In his essay entitled "La historia o la lectura del tiempo," Chartier (2007) analyzes the debates on History as a narrative story since the 1970s. He highlights works such as that of Certeau (1975), which emphasized the discursive nature of History and how this debate shook the foundations of History as a discipline. The textbook is probably the historical narrative most read by society as a whole, and perhaps, the only history narrative people use throughout their lives, along with other informal means of knowledge (mass media, museums, other centers of historical interest, etc.). This is why it is so important to analyze this story, this narrative, which has created so much controversy through its use (and abuse) in education (Foster and Crawford, 2006).

Despite the continuous legislative changes in the field of education in the last 25 years and the different methodological proposals in the teaching of history, in Spain, the textbook continues to be the main didactic material used by teachers of History (Martínez et al., 2009). Not all the countries around us have the same conception and use of textbooks. While in some countries they are usually used in the classroom to cover a large part of the contents of the subject and to prepare students for the exam, in others, they are just one more resource for both the teaching staff and the student.

The reality is that textbooks fulfill a function of transmitting knowledge and the sense of hegemonic reality on the part of the authorities or of power that is generally not questioned in their pages (Gómez et al., 2014). The textbook, as Foster (2011) indicates, is a powerful cultural artifact containing ideas and values that influential sectors of society expect students to learn and reproduce. In Apple's words (1993, quoted by Foster, 2011), textbooks are conceived and designed by real people with real interests. Traditionally, the teaching of history has been seen as the means nations use to seek to spread and reinforce the narratives that define the concepts of nation and national identity (Foster, 2011; Miralles et al., 2012). Textbooks contain many of the stories that nations choose to tell about how their institutions, their legitimacy, their relationships with other nations, and the history of their people were built. Therefore, it is the key to analyze the construction of this story along the lines proposed by Chartier (2007) in order to understand the intentionality of the authorities and other agents of influence on the historical narrative that should be present in the classroom.

Concern about the role of the textbook in teaching History and how textbooks are linked to the construction of collective identities has led to a wealth of international literature, such as the special monographic issue of the International Journal of Historical Learning. Teaching and Research in 2003, the book compiled by Foster and Crawford (2006), the eBook O Manual Escolar no Ensino da História: Visões Historiográficas e Didática coordinated by Solé and Barca (2018), the monographic journal Educational Inquiry in 2011 (vol. 2 num. 1), or the monographs in the journals Ensayos (2014) and Historia y Memoria de la Educación (2017). Articles such as Foster's (2011) provide an interesting overview of theoretical and empirical approaches to textbook analysis, while Nicholls (2003) or Pingel (2010) present the main methods used in textbook research. However, a key reference is undoubtedly the Georg Eckert Institute for International Textbook Research in Braunschweig (Germany), which is one of the world's leading textbook research centers with a large number of research projects covering a considerable number of disciplines The Institute conducts multidisciplinary research on textbooks, mainly for the teaching of history and social and cultural studies.

Elmersjö (2014) emphasizes one of the international projects carried out by the Georg Eckert Institute in collaboration with the Swedish universities of Umeå and Karlstad (Gómez et al., 2014). In Europe, therefore, textbook analysis is a fundamental line of research to understand the tensions in the teaching of history, its problems and relations with power, curricula, the construction of identities, and historical, social, and cultural context. Works such as those by Höpken (1996), Cajani (2006), Baquès (2007), Estivalèzes (2011), and Zachos and Michailidou (2014) have gone into these issues in depth, focusing on the construction of the concept of Europe, the presence of the great social and political traumas (First and Second World Wars, fascism, Nazism, etc.), the different ways of approaching the nation, and the changes in the teaching of History visualized in the manuals.

One of the main lines of research in recent decades has centered on the construction of historical thought and what it means to learn skills in the interpretation of the past, beyond conceptual or memorized knowledge (Wineburg, 2001; Van Sledright, 2014). The origins of historical education research in this line are usually set in the 1980s and 1990s (Lee et al., 2004; Lee, 2005). The first works of this project, from the mid-1980s to the mid-1990s, were based on the analysis of students' historical abilities through the use of historical empathy sources and exercises. More recently, the work of this group has been oriented towards the arguments of students in their explanation of historical processes, combining the management and critique of sources and the different ways of approaching the causality of historical events. In recent years, in the United Kingdom, Chapman (2011) or Cooper (2012, 2013) delve into the arguments of students and their analysis and evaluation of concrete experiences. Elsewhere, Counsell (2011) and Foster (2011) or Harris (2013) focus on the role of historical education in the curriculum, textbooks, and teacher training.

On the other side of the Atlantic, again in the late 1980s and early 1990s, we find the first research works on historical education: Seixas (1993) in Canada or Wineburg (1991) in the USA. The latter used techniques from the field of psychology based on experts and novices (in this case, historians and students) to study what it means to read a historical source and stressed the importance of overcoming presentism. One of the most relevant results of his research is that historical thinking is not a natural ability acquired with psychological development, but requires teaching (Wineburg, 2001).

The research that has influenced the definition of this knowledge of history has multiplied in the 21st century in North America. In the compilation edited by Stearns et al. (2000), with contributions from authors such as Lee, Ashby, Levstik, and Wertsch, there was already a broad reflection 
on the challenges in the teaching of History at the turn of the century. Barton and Levstik (2004), Levstik and Barton (2008), and Van Sledright (2011, 2014) advanced in the reflection on historical thinking and the development of these second-order concepts. Reisman (2012), Wineburg et al. (2013), and Monte-Sano et al. (2014), among others, examine in depth the skills of the historian and the treatment of sources in the classroom.

Noteworthy in Canada are all the publications by the Centre for the Study of Historical Consciousness, directed by Peter Seixas. This center has made a great effort to define historical consciousness and historical thought and to adapt them practically to the reality of the classroom through projects like Historical Thinking Assessment (Seixas, 2004, 2017; Lévesque, 2008; Seixas and Morton, 2013; Ercikan and Seixas, 2015). In addition to this center's efforts, the work on historical education has greatly increased in an attempt to combine the two concepts indicated above: Clark (2011), Létourneau (2014), Zanazanian (2015), or Sandwell and Von Heyking (2014).

In Portugal, Barca (2010), Pinto (2017), Gago (2018), and Solé (2019), and in Spain, López-Facal (2014), Domínguez (2015), Gómez and Miralles (2015, 2016), Sáiz and LópezFacal (2015), Gómez and Sáiz (2017), and Carretero (2019) show how proposals from the English-speaking world have been incorporated into research on historical education. In Latin America, historical education research has developed a great deal since the turn of the century and particularly noteworthy is the research being carried out in Mexico and Brazil (Plá, 2005; Schmidt and Fronza, 2018).

\section{PRESENT STUDY}

In Spain, the analysis of textbooks has been a fruitful line of research over the last 20 years (Valls, 2001, 2007, 2008; Gómez et al., 2014; Ortega et al., 2019). Rafael Valls is the leading Spanish author on this subject and a pioneer in approaching these manuals rigorously and systematically from the didactics of social sciences. From his studies, different themes have been developed in the analysis of textbooks and their relations with the teaching of History in Primary and Secondary Education. The analysis of the contents selected by the manuals is still extremely present. However, this research has been extended to other areas of work such as historical time, the analysis of activities, and their relationship with competences.

Numerous studies have been carried out on textbooks in Portugal in the field of educational history (Matos, 1990; Mendes, 1999) and, more recently, in the field of history education (Magalhães, 2002, 2013; Freitas, 2005; Solé, 2014, 2018; Rodríguez and Solé, 2018; Solé and Barca, 2018). The initial interest was in the analysis of the contents centered on historical themes and on the rigor expressed in them, the analysis of their structure, content, suitability of the methodology, and of the activities and questions posed. Since the 1980s, textbooks have shown greater concern for the nature of history, for making it more objective and scientific, and for a greater rigor in methodological terms (Solé, 2014).
In England, studies on content analysis, often comparative in nature and mainly regarding controversial issues, have been predominant (Grindel, 2012; Gómez and Chapman, 2017).

Due to the paucity of studies on educational competences developed from the activities contained in History textbooks in these countries, this study has focused on the cognitive level of these exercises. The choice of these three countries is due to their different traditions in History education in the case of England which is focused on the development of historical skills, in contrast with Spain's and Portugal's emphasis on conceptual contents and transversal competences.

\section{Research Question, Objectives, and Research Hypothesis}

The research question of this paper is: Are there differences in the cognitive skills demanded in History textbooks in England, Portugal and Spain during the transition from Primary to Secondary education? The following specific objectives are addressed:

-To analyze the cognitive level of the activities according to the country of origin of the textbooks.

$H_{0:}$ There are no statistically significant differences in the cognitive level required by the activities contained in the textbooks of the three countries studied.

$H_{1:}$ There are statistically significant differences in the cognitive level required by the activities contained in the textbooks of the three countries studied.

-To analyze the cognitive level of the activities according to the typology of exercises.

$H_{0:}$ There are no statistically significant differences in the cognitive level of the activities contained in the textbooks according to the typology of the exercises. $H_{1:}$ There are statistically significant differences in the cognitive level of the activities contained in the textbooks according to the typology of the exercises.

-To analyze the cognitive level of the activities according to the historical competences they develop.
$H_{0:}$ There are no statistically significant differences in the cognitive level of the activities contained in the textbooks according to the historical competences developed.
$H_{1:}$ There are statistically significant differences in the cognitive level of the activities contained in the textbooks according to the historical competences developed.

-To analyze the cognitive level of the activities according to the historical contents that they outline.
$H_{0:}$ There are no statistically significant differences between the cognitive level required in the textbooks and the historical contents which are presented in these exercises. $H_{1:}$ There are statistically significant differences between the cognitive level required in the textbooks and the historical contents which are presented in these exercises. 


\section{MATERIALS AND METHODS}

\section{Focus of the Research}

This research has a descriptive quantitative cross-sectional design, as it seeks to ascertain and compare the characteristics of the activities in the History textbooks of England, Portugal, and Spain. A nominal measurement scale is used to classify the activities according to their typology, competences and historical contents, and an ordinal scale for the cognitive level. The frequency of each of these categories is studied together with the comparison of means between the variables.

\section{Sample}

The sample of this study is made up of the activities included in the Spanish, Portuguese, and English History textbooks for pupils aged between 11 and 13, in the transition period between Primary and Secondary Education. These years correspond in Spain to the 6th year of Primary Education and the first 2 years of Compulsory Secondary Education; in England to the 3 years of Key Stage; and in Portugal to the 6th, 7th, and 8th years. Although the sample is non-probabilistic, nine widely distributed publishers were selected. The publishers are Oxford; Santillana and Vicens Vives in Spain; Heinemann, Hodder Education and Collins in England; and Porto Editora, Asa, and Areal in Portugal. The sample consists of 6,561 activities from 27 school textbooks. ${ }^{1}$

\section{Data Collection and Analysis}

An Excel database was designed to collect the data. The qualitative variables, of nominal type, were coded, assigning them a numerical value to facilitate the subsequent quantitative analysis in SPSS v.22.0. According to the type of activity, the typology of the exercise was defined, employing the classification used by Gómez and Miralles (2015). This categorization is shown in Table $\mathbf{1}$.

We took Sáiz (2013) as our reference in defining the cognitive level required in the activities. Bloom's taxonomy of learningobjective stages, in one of its most recent versions, adapted by Anderson and Krathwohl (2001), was applied. Other classifications of basic and higher cognitive skills were taken into account (Ramos et al., 2010), as well as the adaptation of exercises on History and Social Sciences to the development of skills (Hernández, 2002; Vidal-Abarca, 2010). This has enabled us to make a hierarchy of cognitive levels of learning resulting from the activities proposed in the textbooks (Table 2). This taxonomy is based on the hierarchy of learning objectives, which include "memorizing" as the initial task, then "understanding", "applying," "analyzing," "evaluating," and finally, "creating" as the highest level of such objectives. The taxonomy is extremely popular and influential in current educational research and practice (Arievitch, 2020). This review of Bloom's taxonomy has been used in recent years for the metacognitive analysis of exercises and activities in the field of applied didactics such as the didactics of History, Geography, the experimental

${ }^{1}$ We thank María Martínez Hita because she entered half of the activities of textbooks of England and Spain in the database on the framework of it Final Master's Thesis. Also we thank Arthur Chapman for pointing out the most suitable English textbooks for analysis.
TABLE 1 | Type of activities in the textbooks.

\begin{tabular}{|c|c|}
\hline Type of activity & Example \\
\hline $\begin{array}{l}\text { Exercises with } \\
\text { figures/images }\end{array}$ & $\begin{array}{l}\text { How many dictatorships were there in Spain between } \\
1920 \text { and } 1975 ? \text { What characterizes a dictatorship? } \\
\text { Working with the image. What differences do you } \\
\text { observe between the Christian territories at the } \\
\text { beginning of the eleventh century and those in the } \\
\text { thirteenth century? } \\
\text { The first Spanish Constitution was passed in: (a) } 1808 \text {, } \\
\text { (b) } 1812 \text {, and (c) } 1978\end{array}$ \\
\hline Objective tests & $\begin{array}{l}\text { Order chronologically: Caliphate of Cordoba, Taifa } \\
\text { kingdoms, Muslim invasion and emirate, Nasrid kingdom of } \\
\text { Granada. }\end{array}$ \\
\hline Text commentary & $\begin{array}{l}\text { Comment on the text. What was the working day of a } \\
\text { child in the mines? Could they go to school? What do } \\
\text { you think the absence of education meant? }\end{array}$ \\
\hline Essay & $\begin{array}{l}\text { How did the Jews feel about being expelled? Give reasons } \\
\text { for your answer. }\end{array}$ \\
\hline Creation & $\begin{array}{l}\text { Imagine you are a suffragette at the beginning of } \\
\text { the twentieth century. Prepare a poster calling for } \\
\text { women's right to vote. It should include and illustration, a } \\
\text { main slogan and three reasons for defending this right. } \\
\text { In the eleventh century, craftsmen began to form guilds. }\end{array}$ \\
\hline Information search & $\begin{array}{l}\text { Search for the main guilds in the Middle Ages and make a } \\
\text { list of them. }\end{array}$ \\
\hline
\end{tabular}

Source: Own

TABLE 2 | Meaning and examples of the categorization of the cognitive level demanded of students in the textbook activities.

\begin{tabular}{lll}
\hline $\begin{array}{l}\text { Cognitive } \\
\text { level }\end{array}$ & Meaning & Example
\end{tabular}

Locating and repeating information in academic texts and primary or secondary written sources. They activate declarative knowledge that is Which foreign literal or text based. The only skills required are rebels in the reading, description, locating, repeating, reproducing, and/or memorizing.

Those that require understanding the information included in the resource (academic text, source, map, chronological axis, image, etc.): summarizing it, paraphrasing it, or Spanish Civil War? schematizing it; locating the main idea of the 2 resource, summarizing the information offered in it and/or schematizing it; defining concepts, relating, establishing similarities, or differences between them; searching for and summarizing new information in other sources; and finally creating simple resources.

Those that require students to analyze, apply, and evaluate information from different resources or those that involve the creation of new information. They start from the previous level and derive from solving inferential

How was nineteenth century different from the stratified society? questions and the application of procedural contents as strategies. Exercises of historical empathy, simulations or case studies; the writing of simulated biographies applying the declarative contents learned; and the critical or heuristic evaluation of information provided by the sources.

Source: Own, based on the cognitive level categories established by Sáiz (2013). 
sciences and Mathematics (Gómez and Miralles, 2015; Radmehr and Drake, 2018; Virranmäki et al., 2020).

The study of Seixas and Morton (2013) was taken as the basis for the analysis of the presence of first- and second-order concepts (the latter related to historical thinking skills). The proposal was adapted to the textbook activities, as indicated in Table 3. In addition, two typologies of first-order concepts (chronology; conceptual/factual) were added to the secondorder concepts, as has been done in other studies on examinations (Gómez and Miralles, 2015).

The quantitative analysis was performed with SPSS v.22.0. Descriptive statistics were obtained, finding the percentage and absolute frequency of the variables under study. The KolmogorovSmirnov test was run to ensure that the sample had normal parameters and that the parametric tests could be performed. Once it was verified that the variables under study complied

TABLE 3 | Meaning and example of the categorization of first and second-order concepts in the textbook activities.

\begin{tabular}{|c|c|c|}
\hline Concept & Meaning & Example \\
\hline Chronology & $\begin{array}{l}\text { Knowledge of the dates of } \\
\text { historical processes or how to } \\
\text { situate them correctly }\end{array}$ & $\begin{array}{l}\text { Put the following figures in } \\
\text { historical order: Charles I, } \\
\text { James II, William of } \\
\text { Orange, Oliver Cromwell. }\end{array}$ \\
\hline $\begin{array}{l}\text { Conceptual/ } \\
\text { factual }\end{array}$ & $\begin{array}{l}\text { Knowledge of a concept or a } \\
\text { specific fact in the past. }\end{array}$ & $\begin{array}{l}\text { Who were the favorites? } \\
\text { Name two of them. }\end{array}$ \\
\hline $\begin{array}{l}\text { Historical } \\
\text { relevance }\end{array}$ & $\begin{array}{l}\text { Explain the historical relevance of } \\
\text { a particular event or figure using } \\
\text { appropriate criteria. }\end{array}$ & $\begin{array}{l}\text { Why was the printing press } \\
\text { so important for culture? }\end{array}$ \\
\hline $\begin{array}{l}\text { Sources/ } \\
\text { Historical } \\
\text { evidence }\end{array}$ & $\begin{array}{l}\text { Understanding History as an } \\
\text { interpretation based on } \\
\text { inferences from primary sources. }\end{array}$ & $\begin{array}{l}\text { Interpretation of texts or } \\
\text { sources in the manual that } \\
\text { go beyond the } \\
\text { reproduction of a sentence. }\end{array}$ \\
\hline $\begin{array}{l}\text { Change and } \\
\text { continuity }\end{array}$ & $\begin{array}{l}\text { Understanding change in the } \\
\text { past as a process, with various } \\
\text { rhythms and patterns. Identifying } \\
\text { the complex patterns of progress } \\
\text { and decadence in different } \\
\text { peoples or societies. }\end{array}$ & $\begin{array}{l}\text { Humanism supposed a } \\
\text { change of mentality with } \\
\text { respect to the preceding } \\
\text { period. Explain its ideas. }\end{array}$ \\
\hline $\begin{array}{l}\text { Causes and } \\
\text { consequences }\end{array}$ & $\begin{array}{l}\text { Recognizing multiple causes and } \\
\text { consequences in the short and } \\
\text { long term. Seeing the } \\
\text { consequence of a deed or } \\
\text { specific person for human } \\
\text { activities and current structures } \\
\text { and conditions. }\end{array}$ & $\begin{array}{l}\text { Make a list in your exercise } \\
\text { book of the main causes } \\
\text { behind the economic crisis } \\
\text { of the eighteenth century. }\end{array}$ \\
\hline $\begin{array}{l}\text { Historical } \\
\text { perspective }\end{array}$ & $\begin{array}{l}\text { Recognizing the differences } \\
\text { between current beliefs, values } \\
\text { and motivations (world view) and } \\
\text { those of earlier peoples and } \\
\text { societies. Explaining the } \\
\text { perspectives of people in the } \\
\text { past within their historical } \\
\text { context. }\end{array}$ & $\begin{array}{l}\text { [regarding an empathy } \\
\text { activity with two invented } \\
\text { figures from Ancient Egypt] } \\
\text { Imagine you are Merit and } \\
\text { you wrote a letter to your } \\
\text { brother. In your letter } \\
\text { explain what the district } \\
\text { you live in is like... }\end{array}$ \\
\hline $\begin{array}{l}\text { Ethical } \\
\text { dimension }\end{array}$ & $\begin{array}{l}\text { Make reasoned ethical } \\
\text { judgments about people in the } \\
\text { past, taking into account their } \\
\text { historical context. Assess the } \\
\text { implications for today of the } \\
\text { sacrifices and injustices of the } \\
\text { past. }\end{array}$ & $\begin{array}{l}\text { William used terror to try to } \\
\text { control the English, but } \\
\text { how sensible do you think } \\
\text { this was and why? }\end{array}$ \\
\hline
\end{tabular}

Source: Gómez and Miralles, 2016. with these parameters of normality (Sig <0.05), the ANOVA tests between the cognitive level of each one of the exercises with the rest of variables and the Tukey $B$ post-hoc test were applied to check the subsets.

\section{RESULTS}

\section{Cognitive Level by Country of Origin}

There is no great difference in the number of activities according to the country of origin (Table 4). In the sample of activities as a whole, the differences between England $(n=2,365)$, Spain $(n=2,237)$, and Portugal $(n=1,959)$ are small. Nevertheless, one important difference is observed at the cognitive level between Spain (1.43) and Portugal (1.44) and that of England (2.44). The Tukey $B$ test confirms that the History and Social Sciences textbooks published in Spain and Portugal include activities mostly situated between a basic and intermediate cognitive level, whereas in England, textbooks require students to have an intermediate to high level (Table 4). This difference in means is statistically significant according to the ANOVA test $(p<0.05$; Table 5).

\section{Cognitive Level According to Typology of Question}

The difference in the cognitive level of the activities according to the typology of questions is also visible (Table 6). Specifically, the Tukey $B$ post-hoc test identifies five homogeneous subsets according to cognitive level and type of activity. The data analyzed show that the activities, which require students to create contents (2.68) or write an essay, require a high cognitive level (2.74). On the other hand, the rest of the activities are associated to a low cognitive level, with the objective tests requiring the lowest cognitive capacity of the students (1.11). It is also evident that the greatest number of activities is

TABLE 4 | Cognitive level by countries and results of Tukey B test.

\begin{tabular}{|c|c|c|c|c|c|}
\hline & \multirow[t]{2}{*}{$N$} & \multirow[t]{2}{*}{ Mean } & \multirow{2}{*}{$\begin{array}{l}\text { Standard } \\
\text { deviation }\end{array}$} & \multicolumn{2}{|c|}{$\begin{array}{c}\text { Tukey } B^{a, b} \\
\text { Subset for alpha }=0.05\end{array}$} \\
\hline & & & & 1 & 2 \\
\hline Spain & 2,237 & 1.43 & 0.573 & 1.43 & \\
\hline Portugal & 1,959 & 1.44 & 0.651 & 1.44 & \\
\hline England & 2,365 & 2.44 & 0.587 & & \\
\hline Total & 6,561 & 1.80 & 0.774 & & 2.44 \\
\hline
\end{tabular}

a Using the sample size from the harmonic mean $=2,173.402$

${ }^{b}$ Group sizes are not equal. Type 1 levels are not guaranteed.

TABLE 5 | ANOVA test between cognitive level and country of origin.

\begin{tabular}{lccccc}
\hline & $\begin{array}{c}\text { Sum of } \\
\text { squares }\end{array}$ & GI & $\begin{array}{c}\text { Quadratic } \\
\text { mean }\end{array}$ & $\boldsymbol{F}$ & Sig. \\
\hline Between groups & $1,546.379$ & 2 & 773.189 & $2,130.291$ & 0.000 \\
Within groups & $2,380.228$ & 6,558 & 0.363 & & \\
Total & $3,926.607$ & 6,560 & & &
\end{tabular}


TABLE 6 | Cognitive level according to typology of activity and results of Tukey $B$ test.

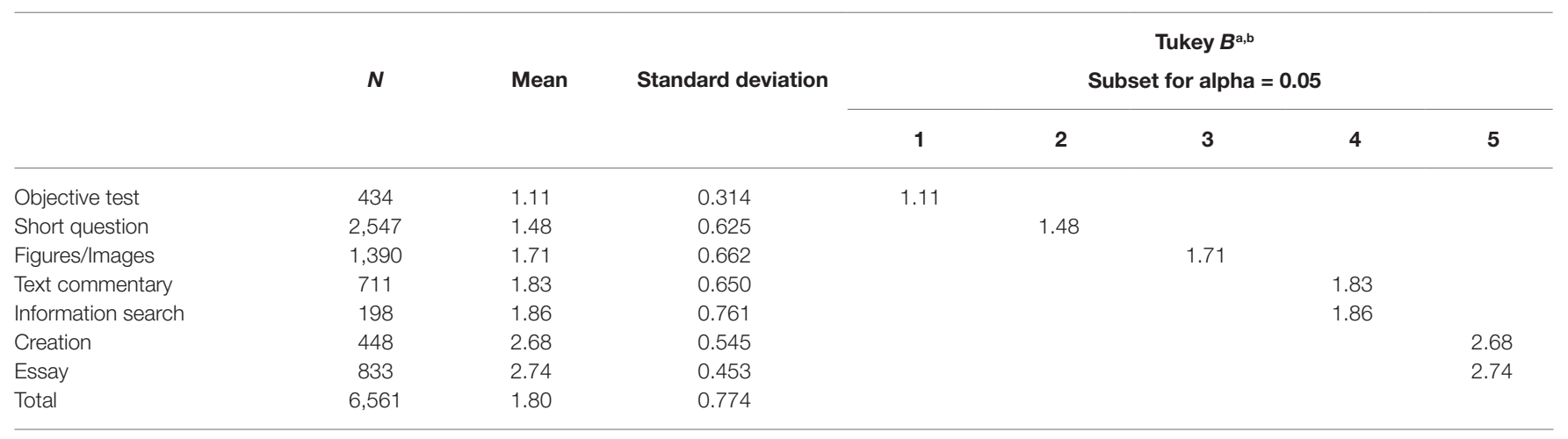

Table shows the means for the groups in the homogeneous subsets.

alt uses the size of the sample of the harmonic mean $=526.087$.

${ }^{b}$ Group sizes are not equal. The harmonic mean of the group sizes is used.

Type 1 error levels are not guaranteed.

associated with types with a low cognitive level, such as short questions $(n=2,547)$ or those that include figures and images $(n=1,390)$, while those linked to a higher cognitive level, such as content creation, are less present in textbooks ( $n=448$; Table 6). The ANOVA test confirms that these differences are statistically significant $(p<0.05$; Table 7$)$.

\section{Cognitive Level According to Historical Thinking Concepts}

As far as the cognitive level is concerned, according to the concepts of historical thinking among the eight established categories-two related to first-order and six to second-order concepts-there are notable differences in means (Table 8). The Tukey $B$ test establishes five homogeneous subsets that place the categories related to the first-order historical concepts, "Chronology" and "Conceptual/factual" at a low cognitive level (1.28 and 1.32, respectively), while the rest are placed in the intermediate cognitive level, emphasizing the historical "Empathy/ Perspective" as the concept that places greatest cognitive level demands on the students, close to level 3 (2.88). In addition, the historical concept that has the most presence in the textbook activities is "Conceptual/factual" $(n=2,855)$ and "Sources/evidence" ( $n=1,607$ ) while, in contrast, the one that appears least is "Historical Consciousness" ( $n=143$; Table 8). These differences are significant according to the ANOVA test ( $p<0.05$; Table 9).

\section{Cognitive Level According to the Typology of the History Content}

Finally, in the relationship between cognitive levels and the typology of History contents, there is also a difference in means, albeit not as high as in the other categories (Table 10). The results indicate that political and institutional History is the most worked on in the activities $(n=2,986)$ followed by social and economic History $(n=2,290)$. On the other hand are the contents related to History of Art and Culture $(n=1,022)$ and General History $(n=262)$. Social and economic history activities are quite close to an intermediate cognitive level (1.96), while activities related to contents on the history of art and culture
TABLE 7 | ANOVA test between cognitive level and type of activity.

\begin{tabular}{lccccc}
\hline & $\begin{array}{c}\text { Sum of } \\
\text { squares }\end{array}$ & GI & $\begin{array}{c}\text { Quadratic } \\
\text { mean }\end{array}$ & $\boldsymbol{F}$ & Sig. \\
\hline Between groups & $1,562.980$ & 6 & 260.497 & 722.320 & 0.000 \\
Within groups & $2,363.626$ & 6,554 & 0.361 & & \\
Total & $3,926.607$ & 6,560 & & & \\
\hline
\end{tabular}

have the lowest cognitive level (1.54) according to the Tukey $B$ post-hoc test (Table 10). The ANOVA test confirms that these differences are statistically significant $(p<0.05$; Table 11).

\section{DISCUSSION AND CONCLUSION}

After analyzing more than 6,500 textbook activities from three different countries, we cannot reject the alternative hypotheses: there are statistically significant differences between the cognitive level of the activities and the countries of origin, the type of exercises, the historical competences that they develop, and the contents proposed. With this analysis, it is possible to deduce which exercises require a greater or lesser cognitive effort on the part of the pupils. Essay-writing and creative activities which work on empathy, perspective and historical consciousness, and which develop social and economic history contents, are those which present a greater cognitive level (moderate to high). On the other hand, short questions and objective tests focusing on chronology and first-order contents (facts and concepts), and which develop history of art contents, are those which present a lower cognitive level. While textbooks from England employ the former typology of activities, Spanish and Portuguese manuals contain a higher percentage of activities with a low cognitive level.

Among the main causes for this difference between the three countries, the different curricular approaches and epistemological conceptions of the teaching of history stand out. In England, the historical competences (empathy, historical argumentation, causes and consequences, etc.) are prescriptive elements of the curriculum. There is a recommended list of first-order contents (facts, reigns, concepts, etc.), although they are not obligatory. 
TABLE 8 | Cognitive level according to historical concepts and results of Tukey $B$ test.

\begin{tabular}{|c|c|c|c|c|c|c|c|c|}
\hline & \multirow{3}{*}{$N$} & \multirow{3}{*}{ Mean } & \multirow{3}{*}{ Standard deviation } & \multirow{2}{*}{\multicolumn{5}{|c|}{$\begin{array}{c}\text { Tukey } B^{\mathrm{a}, \mathrm{b}} \\
\text { Subset for alpha }=0.05\end{array}$}} \\
\hline & & & & & & & & \\
\hline & & & & 1 & 2 & 3 & 4 & 5 \\
\hline Chronology & 220 & 1.28 & 0.459 & 1.28 & & & & \\
\hline Conceptual/Factual & 2,855 & 1.32 & 0.510 & 1.32 & & & & \\
\hline Sources/Evidence & 1,607 & 2.00 & 0.716 & & 2.00 & & & \\
\hline Causes and consequences & 498 & 2.10 & 0.677 & & 2.10 & & & \\
\hline Change and continuity & 489 & 2.25 & 0.687 & & & 2.25 & & \\
\hline Historical relevance & 327 & 2.44 & 0.657 & & & & 2.44 & \\
\hline Historical consciousness & 143 & 2.50 & 0.592 & & & & 2.50 & \\
\hline Empathy/Perspective & 421 & 2.88 & 0.343 & & & & & \\
\hline Total & 6,560 & 1.80 & 0.774 & & & & & 2.88 \\
\hline
\end{tabular}

Table shows the means for the groups in the homogeneous subsets.

alt uses the size of the sample of the harmonic mean $=363.679$.

${ }^{b}$ Group sizes are not equal. The harmonic mean of the group sizes is used.

Type 1 error levels are not guaranteed.

TABLE 9 | ANOVA test between cognitive level and historical concepts.

\begin{tabular}{lccccc}
\hline & $\begin{array}{c}\text { Sum of } \\
\text { squares }\end{array}$ & Gl & $\begin{array}{c}\text { Quadratic } \\
\text { mean }\end{array}$ & $\boldsymbol{F}$ & Sig. \\
\hline Between groups & $1,616.146$ & 7 & 230.878 & 654.904 & 0.000 \\
Within groups & $2,309.824$ & 6,552 & 0.353 & & \\
Total & $3,925.970$ & 6,559 & & & \\
\hline
\end{tabular}

These first-order contents are the elements which make it possible to develop the previously mentioned competences. On the other hand, in Portugal and Spain, there is a list of first-order contents which are for prescriptive learning, the inheritance of a model of General History. This approach to the teaching of History was defined in the 19th century and aimed to teach all historical events chronologically, be they of a nation/State or the whole of humanity (Valls and Colomer, 2018). This model is primarily based on the national narrative which is accepted and promoted by the institutions of power and which normally eclipses all other alternative narratives (López-Facal, 2014; Ender, 2019). The greater freedom of the English curriculum allows textbooks to contain a greater number of essay-writing and creative activities regarding contents of social and economic History, whereas, although these types of activities exist in Portuguese and Spanish textbooks, these focus more on the knowledge (mainly based on memorization) of characters, events, and reigns related with the institutions of power and with a national and European narrative (Carretero and Van Alphen, 2014; Gómez and Chapman, 2017).

The different approach of the English curriculum is the consequence of the remarkable impact of projects such as Concepts History and Teaching Approaches (CHATA) and the changes introduced by the National Curriculum of 1991 (Cooper and Chapman, 2009; Byrom, 2013). The CHATA project, which continued into the early years of the 21st century, was based on the acquisition of second-order concepts by pupils and on the establishment of levels of progression of this knowledge in ages ranging from 7 to 14 (Domínguez, 2015). In this regard, the contributions made since the 1980 s by a large number of authors (Lee et al., 2004; Lee, 2005) are of great interest as they advocated a form of history teaching which included, in a balanced way, both conceptual and procedural contents, which they began to call second-order concepts (Martínez-Hita and Gómez, 2018).

In Spain, Ley Orgánica (8/2013), for the improvement of educational quality provides the framework for Real Decreto (126/2014), 28th of February, which establishes the basic curriculum of Primary Education (pupils aged 6-11), and Real Decreto (1115/2014), 26th of December, which establishes the basic curriculum of Compulsory Secondary Education and Baccalaureate (pupils aged 12-17). In both educational stages, the programming of objectives, contents and evaluation criteria, and evaluable learning standards are centered on the transmission of disciplinary theoretical knowledge, with there being very little of significance on the teaching of skills that require active learning methods and the continuous evaluation of the learner. Indeed, the main criticisms are the large volume of theoretical content and the excessive number of evaluable learning standards, which condition a teaching model centered on the teacher and characterized by the predominance of the master class and the final assessment of the students (López-Facal, 2014).

In Portugal, the Currículo Nacional do Ensino Básico (6-15 years) and Ensino Secundario (16 to 18 years) Currículo Nacional - DL (139/2012) regulated the education system until its reform in 2018. Criticism of the Portuguese curriculum has been quite similar to that in Spain both in terms of the extension of content programs and the traditional teaching approach. Indeed, the Curricular Goals introduced in education legislation in 2011/12 (Ministério da Educação e Ciência (MEC-DGS), 2013) are similar to the evaluable learning standards of the Spanish curriculum. In both cases, the student learning process is centered on the reproduction of contents acquired fundamentally through memorization, and consequently, the teaching-learning process revolves around a low cognitive level. The latest legal review in Portugal incorporates the document Aprendizagens Essencias, Despacho no. 6944-A (2018) dated 19 July 2018, which goes beyond disciplinary contents, that is, significant, 
TABLE 10 | Cognitive level cognitive according to historical contents and results of Tukey $B$ test.

\begin{tabular}{|c|c|c|c|c|c|c|}
\hline & \multirow[t]{2}{*}{$\mathbf{N}$} & \multirow[t]{2}{*}{ Mean } & \multirow[t]{2}{*}{ Standard deviation } & \multicolumn{3}{|c|}{$\begin{array}{c}\text { Tukey } B^{a, b} \\
\text { Subset for alpha }=0.05\end{array}$} \\
\hline & & & & 1 & 2 & 3 \\
\hline History of art and cultural & 1,022 & 1.54 & 0.644 & 1.54 & & \\
\hline General history & 262 & 1.73 & 0.771 & & 1.73 & \\
\hline Political and institutional history & 2,986 & 1.77 & 0.782 & & 1.77 & \\
\hline Social and economic History & 2,290 & 1.96 & 0.779 & & & 1.96 \\
\hline Total & 6,560 & 1.80 & 0.774 & & & \\
\hline
\end{tabular}

Table shows the means for the groups in the homogeneous subsets.

alt uses the size of the sample of the harmonic mean $=718,540$.

${ }^{b}$ Group sizes are not equal. The harmonic mean of the group sizes is used.

Type 1 error levels are not guaranteed.

TABLE 11 | ANOVA test between cognitive level and historical contents.

\begin{tabular}{lccccc}
\hline & $\begin{array}{c}\text { Sum of } \\
\text { squares }\end{array}$ & GI & $\begin{array}{c}\text { Quadratic } \\
\text { mean }\end{array}$ & $\boldsymbol{F}$ & Sig. \\
\hline Between groups & 133.303 & 3 & 44.434 & 76.809 & 0.000 \\
Within groups & $3,792.667$ & 6,556 & 0.579 & & \\
Total & $3,925.970$ & 6,559 & & & \\
\hline
\end{tabular}

indispensable, and relevant knowledge, and seeks to value the abilities and attitudes that students must develop. In other words, it again values teaching in which the competences are recognized as indispensable. It deals with what students must know, the cognitive processes they must activate in order to acquire this knowledge, and also the know-how, or the transformation, of this knowledge into new learning. It is oriented towards the Perfil dos Alunos à Saída da Escolaridade Obrigatória, Despacho no. 6478 (2017), dated 26 July 2017. The document incorporates contributions on teaching and learning from international reference bodies (the European Union, the Organization for Economic Cooperation and Development and the United Nations Educational, Scientific and Cultural Organization), as well as recent research in education and curricular documents from other countries.

The high presence of objective tests and short questions in Spain and Portugal do not require comprehension tasks on the part of the pupils nor the application of new knowledge; consequently, they are at a low cognitive level. This type of activity is also frequently used in student assessment instruments (Trepat, 2011; Gómez and Miralles, 2015; Merchán, 2015), which corroborates the fact that in countries like Spain and Portugal (despite the changes made in the latter since 2017) priority is given to the reproduction of memorized content, with no process of critical reflection or significant learning.

It is true that the analysis of primary and secondary sources is present in all the curricula of the countries analyzed, as is reflected in the high number of activities related to the commentary of texts or the inclusion of figures and images. However, this widespread presence in the activities of History and Social Sciences books does not imply a high cognitive level, as in most cases, these sources have an illustrative function and are not used to encourage students to ask questions about them, or to compare information and draw conclusions that confirm or modify the initial hypotheses regarding a historical fact. In short, the activities that could put pupils in contact with the scientific method of History as a discipline, with the job of the historian, are limited to the demand for a descriptive analysis of the same, which is of little use in learning historical skills (Sáiz, 2014). This has been found in other European countries such as France (Van Nieuwenhuyse, 2016) and Holland (Kleppe, 2010). For all these reasons, the activities in History and Social Sciences textbooks that include the presence of texts, figures, or images are at a low cognitive level.

This way of conceiving History gives greater importance to political events, giving the discipline a marked positivist bias that we can still find today in Spanish and Portuguese textbooks of History and Social Sciences, and which is demonstrated by the high number of activities focusing on political and institutional content. The contents of Social and Economic History, with fewer contents and activities, allow publishers to deploy a rich repertoire of images, figures, and graphic designs that make the textbooks visually appealing. Art and culture appear have a low presence in all the books analyzed, mainly as support material, as they do in the state curricula, and therefore, their function in the activities is limited to descriptive tasks of the proposed sources.

In contrast, the search for information, the creation of contents, and the writing of essays are at an intermediate to high cognitive level. This type of activity has been found, above all, in History textbooks from England, where, from the early stages of education, pupils are encouraged to reflect critically on historical phenomena and facts from sources, using strategies of inquiry (project work, problem-based learning, etc.) and simulation (role playing, gamification, etc.).

The cognitive level demanded by the activities analyzed in Spanish and Portuguese textbooks is low. This is not only the case when comparing them with English textbooks. There are other studies on the cognitive level of textbooks and examinations using this revised version of Bloom's taxonomy which show significant differences with the results found. One example are the intermediate accounting textbooks, which only contain $10 \%$ of activities of cognitive level 1 (memorization and reproduction of contents), compared with $62 \%$ of application and analysis exercises (Davidson and Baldwin, 2005). There are also differences 
with the Finnish Geography examinations analyzed, in which $28 \%$ of the exercises was of level 1, compared to $72 \%$ of comprehension, application, and creation activities (Virranmäki et al., 2020). Furthermore, there are differences with the analysis of digital textbooks carried out by Hung Lau et al. (2018). The approach of the curriculum and the hegemony of a model of History education based on the national narrative are an obstacle to the cognitive demands of the activities of History textbooks.

The curriculum is therefore fundamental when it comes to improving the teaching of history. The insertion of second-order concepts or historical competences, together with the traditional first-order concepts, is fundamental if students are to learn to think historically and be citizens who are critical of the world around them. The last reform carried out in Portugal with the incorporation into the curriculum of the Aprendizagens Essenciais, Despacho no. 6944-A (2018) of 19 July 2018, is situated in this line. It constitutes a shift towards a more Anglo-Saxon approach to teaching, centered on teaching second-order historical concepts related to historical thinking. In addition, greater flexibility in content programming and greater investment in schools have led Portugal to significantly improve its PISA test score in recent years. This is not the case of Spain, whose most recent educational reform continues to be anchored in a traditional teaching approach, with an excessive content curriculum, a history teacher training that retains strong deficiencies and a public school network in need of material and human resources. Perhaps the greatest changes in the medium term can be seen in the area of initial teacher training, due to the improvements made to the curricula in Spanish universities to include subjects related to the teaching of the Social Sciences. In addition, there is the challenge of connecting the scientific environment of universities, where pioneering research on innovative methods and strategies for learning about history is carried out, with educational centers in order to achieve a transfer of knowledge that represents a significant improvement in History teaching.

\section{LIMITATIONS AND FUTURE RESEARCH}

Among the limitations of this paper are that we can point out the unidimensionality of the source studied and the need to combine quantitative and qualitative methods. Furthermore, this paper does not delve into the use that the teacher makes of the textbook. Not all teachers use the textbook in the same way. There is a margin of professional autonomy when deciding how to use these materials. Therefore, this study analyzes the suitability of textbooks according to the countries of origin and the type of exercises they contain. But it does not delve into the use that teachers make of these textbooks and the

\section{REFERENCES}

Anderson, L. W., and Krathwohl, D. R. (2001). A taxonomy for learning, teaching and assessing: A revision of Bloom's taxonomy of educational objectives. Complete Edn. New York: Longman.

Apple, M. W. (1993). Official knowledge: Democratic education in a conservative age. London: Routledge. possible differences according to the countries or the level of training of the teachers.

New lines of research must go this way. The new concept of a textbook should be studied, as it becomes a bank of audiovisual and multimedia resources. In this paper, we have analyzed the student textbook. But publishers for a few years have been providing teachers with other online resources. A new research challenge is to compare these online resources for teachers. It would also be necessary to analyze the use of the textbook by students and teachers: good practices and the effectiveness of its use in the conceptual change in students and their preconceptions and ideas. Finally, the degree of acceptance of the manuals among the teachers according to their previous training and their methodological and epistemological conceptions of history should also be analyzed.

To advance in these lines of research, a combination of sources and quantitative and qualitative approaches would be necessary. In addition to the analysis of the textbook exercises, interviews and discussion groups with teachers and students should be carried out. In this combination of sources, the use and preference of textbook exercises by teachers and students should be investigated on the basis of the sociodemographic and predictive variables indicated above.

\section{DATA AVAILABILITY STATEMENT}

The datasets generated for this study are available on request to the corresponding author.

\section{AUTHOR CONTRIBUTIONS}

CG and PM: conceptualization, methodology, validation, funding acquisition, and resources. CG and GS: software, investigation, and data curation. CG, GS, PM, and RS: formal analysis, writing-review, and editing. CG: writing-original draft preparation. CG, GS, and RS: visualization. PM: supervision and project administration. All authors contributed to the article and approved the submitted version.

\section{FUNDING}

This research was funded by the "Spanish Ministry for Science, Innovation and Universities, Secretary of State for Universities, Research, Development and Innovation," grant number PGC2018094491-B-C33, "Seneca Foundation, Regional Agency for Science and Technology," grant numbers 20638/JLI/18 and 20874/PI/18, and CEIR Campus Mare Nostrum. We would like to thank the above. 25, 1-6. doi: 10.1016/j.lcsi.2019.01.007

Baquès, M. -C. (2007). L'évolution des manuelsd'histoire du lycée. Des années 1960 aux manuelsactuels. Hist. l'Educ. 114, 121-149. doi: 10.4000/histoire-education.1249

Barca, I. (2010). Narrativas e consciência histórica dos jovens. Ens. Ci. Soc. $10,23-29$. 
Barton, K., and Levstik, L. (2004). Teaching history for the common good. Mahwah, NJ: Lawrence Erlbaum Associates Publishers.

Byrom, J. (2013). Alive.... and kicking? Some personal reflections on the revised National Curriculum (2014) and what we might do with it. Teach. Hist. $153,6-14$.

Cajani, L. (2006). "Italian history textbooks on the brink of the twenty-first century" in School history textbooks across cultures: International debates and perspectives. ed. J. Nicholls (Oxford: Symposium Books), 27-41.

Carbone, G. (2003). Libros escolares: una introducción a su análisis y evaluación. Buenos Aires: Fondo de Cultura Económica.

Carretero, M. (2019). Pensamiento histórico e historia global como nuevos desafíos para la enseñanza. Cua. Ped. 495, 59-63.

Carretero, M., and Van Alphen, F. (2014). Do master narratives change among high school students? A characterization of how National History is represented. Cogn. Instr. 32, 290-312. doi: 10.1080/07370008.2014.919298

Certeau, M. (1975). L'escriture de l'histoire. Paris: Garamond.

Chapman, A. (2011). "Historical Interpretations" in Debates in history teaching. ed. I. Davies (London: Routledge), 96-109.

Chartier, R. (2007). La historia o la lectura del tiempo. Madrid: Gedisa.

Clark, P. (ed.) (2011). New possibilities for the past. Shaping history education in Canada. Vancouver-Toronto: UBC Press.

Cooper, H. (2012). History 5-11. A guide for teachers. London: Routledge.

Cooper, H. (ed.) (2013). Teaching history creatively. London: Routledge.

Cooper, H., and Chapman, A. (eds.) (2009). Constructing history, 11-19. London: Sage.

Counsell, C. (2011). Disciplinary knowledge for all, the secondary history curriculum and history teachers' achievement. Curric. J. 22, 201-225. doi: 10.1080/09585176.2011.574951

Currículo Nacional - DL (139/2012). Ministério de Educação e Ciência (MEC- DGS). Portugal. Available at: https://data.dre.pt/eli/dec-lei/139/2012/ 07/05/p/dre/pt/html (Accessed July 5, 2019).

Davidson, R. A., and Baldwin, B. A. (2005). Cognitive skills objectives in intermediate accounting textbooks: evidence from end-of-chapter material. J. Account. Educ. 23, 79-95. doi: 10.1016/j.jaccedu.2005.05.001

Despacho no. 6478 (2017). 26 de julio de 2017. Perfil dos Alunos à Saída da Escolaridade Obrigatória. Available at: https://cutt.ly/weCujAe (Accessed July 5, 2019).

Despacho no. 6944-A (2018). de 19 de julio de 2018. Aprendizagens Essenciais. Available at: https://cutt.ly/beCulDI (Accessed July 5, 2019).

Domínguez, J. (2015). Pensamiento histórico y evaluación de competencias. Barcelona: Graó.

Elmersjö, H. A. (2014). History beyond borders: peace education, history textbooks revision, and the internationalization of history teaching in the twentieth century. Hist. Enc. 1, 62-74.

Ender, T. (2019). Counter-narratives as resistance: creating critical social studies spaces with communities. J. Soc. Stud. Res. 43, 133-143. doi: 10.1016/j.jssr.2018.11.002

Ercikan, K., and Seixas, P. (2015). Issues in designing assessment of historical thinking. Theory Pract. 54, 255-262. doi: 10.1080/00405841.2015.1044375

Estivalèzes, M. (2011). Teaching about Islam in the history curriculum and in textbooks in France. J. Educ. Med. Mem. Soc. 7, 45-60. doi: 10.3167/ jemms.2011.030104

Foster, S. (2011). Dominant tradition in international textbooks research and revision. Educ. Inq. 2, 5-20. doi: 10.3402/edui.v2i1.21959

Foster, S. J., and Crawford, K. A. (eds.) (2006). What shall we tell the children? International perspectives on school history textbooks. Greenwich, CT: Information Age Publishing.

Freitas, M. L. (2005). "História de Portugal no 1. ciclo do ensino básico: Os programas, os manuais e as vozes dos alunos" in Actas do 8. Congresso Galaico-Português de Psicopedagogia. eds. C. B. Silva and L. Almeida (Braga: Universidade do Minho), 2135-2149.

Gago, M. (2018). Consciência histórica e narrativa na aula de História- concepções de professores. Porto: Edições Afrontamento.

Gómez, C. J., and Chapman, A. (2017). Enfoques historiográficos y representaciones sociales en los libros de texto. Un estudio comparativo, España-Francia-Inglaterra. Historia y Memoria de la Educación 6, 319-361. doi: 10.5944/hme.6.2017.17132

Gómez, C. J., Cózar, R., and Miralles, P. (2014). La enseñanza de la historia y el análisis de libros de texto. Construcción de identidades y desarrollo de competencias. Ensayos 29, 1-25.
Gómez, C. J., and Miralles, P. (2015). Pensar históricamente o memorizar el pasado? La evaluación de los contenidos históricos en la Educación Obligatoria en España. Rev. Est. Soc. 52, 52-68. doi: 10.7440/res52.2015.04

Gómez, C. J., and Miralles, P. (2016). Devéloppement et évaluation des compétenceshistoriquesdans les manuales scolaires. Une étudecomparative France-Spagne. Spirale 68, 55-66. doi: 10.3917/spir.058.0053

Gómez, C. J., and Sáiz, J. (2017). Narrative inquiry and historical skills. A study in teacher training. Rev. Elec. Inv. Educ. 19, 19-32. doi: 10.24320/ redie.2017.19.4.910

Grindel, S. (2012). Colonialism in textbooks as translation problem German, French and English history textbooks in comparison. Gesch. Ges. 38, 272-303. doi: 10.13109/gege.2012.38.2.272

Harris, R. (2013). The place of diversity within history and the challenge of policy and curriculum. Oxf. Rev. Educ. 39, 400-419. doi: 10.1080/03054985.2013.810551

Hernández, X. (2002). Didáctica de las ciencias sociales, geografía e historia. Barcelona: Graó.

Höpken, W. (ed.) (1996). ÖlinsFeuer. Schulbücher, ethnischeStereotypenundGewalt in Südosteuropa/OilonFire? Textbooks, ethnic, stereotypes and violence in SouthEastern Europe. Hannover: Hahnsche Buchhandlung.

Hung Lau, K., Lam, T., Hon Kam, B., Nkhoma, M., Richardson, J., and Thomas, S. (2018). The role of textbook learning resources in e-learning: a taxonomic study. Comput. Educ. 118, 10-24. doi: 10.1016/j.compedu.2017.11.005

Kleppe, M. (2010). "Photographs in Dutch history textbooks: quantity, type and educational use" in Das Bild im Schulbuch. eds. C. Heinze and E. Matthes (Bad Heilbrunn: Verlag Julius Klinkhardt), 261-272.

Lee, P. (2005). "Putting principles into practice: understanding history" in How students learn: History in the classroom. eds. M. S. Donovan and J. D. Bransford (Washington, DC: National Academies Press), 29-78.

Lee, P., Dickinson, A., and Ashby, R. (2004). "Las ideas de los niños sobre la historia" in Aprender y pensar la historia coords. eds. M. Carretero and J. F. Voss (Buenos Aires: Amorrortu), 217-248.

Létourneau, E. (2014). Démographie et insertion professionnelle: une étude sur le personnel enseignant des commissions scolaires du Québec. Available at: https://cutt.ly/weZXibj

Lévesque, S. (2008). Thinking historically. Educating students for the 21st century. Toronto: University of Toronto Press.

Levstik, L., and Barton, K. (2008). Doing history: Investigating with children in elementary and middle schools. Mahwah NJ: Lawrence Erlbaum Associates.

Ley Orgánica (8/2013). de 9 de diciembre, para la mejora de la calidad educativa. Spain.

López-Facal, R. (2014). La LOMCE y la competencia histórica. Ayer 94, 273-285.

Magalhães, O. (2002). Concepções de História e de Ensino de História. Um estudo no Alentejo. Lisbon: Edições Colibri, CIDEHUS-UE.

Magalhães, O. (2013). "Em torno da escolha do manual escolar: opções de professors" in Didática, História e manuais escolares: contextos ibero-americanos. eds. o. T. García, M. A. Schmidt and R. Valls (Ijuí: Editora Unijuí), 231-246.

Martínez, N., Valls, R., and Pineda, F. (2009). El uso del libro de texto de Historia de España en Bachillerato: diez años de estudio, 1993-2003 y dos reformas (LGE-LOGSE). Did. Ci. Exp. Soc. 23, 3-35.

Martínez-Hita, M., and Gómez, C. J. (2018). Nivel cognitivo y competencias de pensamiento histórico en los libros de texto de Historia de España e Inglaterra. Un estudio comparativo. Rev. Educ. 379, 145-169. doi: 10.4438/1988-592X-RE-2017-379-364

Matos, S. C. (1990). História, Mitologia, Imaginário Nacional: A história no Curso dos Liceus (1895-1939). Lisbon: Livros Horizonte.

Mendes, J. A. (1999). "Identidade Nacional e ideologia através dos manuais de História" in Manuais Escolares: estatuto, funções, história, org. ed. R. V. Castro (Braga: Universidade do Minho), 343-354.

Merchán, F. J. (2015). Evaluación o inculpación? Rev. Soc. Educ. 8, 224-237. Ministério da Educação e Ciência (MEC-DGS) (2013). Metas Curricularesde História do Ensino Básico. Available at: https://www.dge.mec.pt/sites/default/ files/Basico/Legislacao/despacho_5122_2013 (Accessed September 2, 2020).

Miralles, P., Prats, J., and Tatjer, M. (2012). Conocimientos y concepciones de estudiantes españoles y latinoamericanos de Educación Secundaria Obligatoria sobre las independencias políticas americanas. Scripta Nova. Rev. Elec. Geo. Ci. Soc. 16:418. 
Monte-Sano, C., De la Paz, S., and Felton, M. (2014). Teaching argument writing and "content" in diverse middle school history classrooms. Soc. Educ. 79, 194-199.

Nicholls, J. (2003). Methods in school textbooks research. Int. J. Hist. Learn. Teach. Res. 3, 11-26. doi: 10.18546/HERJ.03.2.02

Ortega, D., Sanz de la Cal, E., and Ibáñez, J. (2019). Literacies and development of social, critical, and creative thought in textbooks activities for primary education in social sciences and the Spanish language. Front. Psychol. 10:2572. doi: 10.3389/fpsyg.2019.02572

Pavón, V., Ávila, J., Gallego, A., and Espejo, R. (2014). Strategic and organisational considerations in planning CLIL: a study on the coordination between content and language teachers. Int. J. Biling. Educ. Biling. 18, 409-425. doi: $10.1080 / 13670050.2014 .909774$

Pingel, F. (2010). UNESCO guidebook on textbook research and textbook revision. Braunschweig, Germany: GEI/UNESCO.

Pinto, H. (2017). A interculturalidadeem Educação patrimonial: desafios o contributos para o ensino de História. Educ. Rev. 63, 205-220. doi: $10.1590 / 0104-4060.48650$

Plá, S. (2005). Aprender a pensar históricamente. La escritura de la historia en el bachillerato. México: Plaza y Valdés.

Radmehr, F., and Drake, M. (2018). An assessment-based model for exploring the solving of mathematical problems: utilizing revised bloom's taxonomy and facets of metacognition. Stud. Educ. Eval. 59, 41-51. doi: 10.1016/j.stueduc.2018.02.004

Ramos, A. I., Herrera, J. A., and Ramírez, M. S. (2010). Desarrollo de las habilidades cognitivas con aprendizaje móvil: un estudio de casos. Comunicar 17, 201-209. doi: 10.3916/C34-2010-03-20

Real Decreto (1115/2014). de 26 de diciembre, por el que se establece el currículo básico de la Educación Secundaria Obligatoria y del Bachillerato. Ministerio de Educación, Cultura y Deporte de España.

Real Decreto (126/2014). de 28 de febrero, por el que se establece el currículo básico de la Educación Primaria. Ministerio de Educación, Cultura y Deporte de España.

Reisman, A. (2012). Reading like a historian: a document-based history curriculum intervention in urban high schools. Cogn. Instr. 30, 86-112. doi: 10.1080/07370008.2011.634081

Rodríguez, R., and Solé, G. (2018). Los manuales escolares de Historia en España y Portugal. Reflexiones sobre su uso en educación Primaria y Secundaria. Arbor 194:444. doi: 10.3989/arbor.2018.788n2004

Sáiz, J. (2013). Alfabetización histórica y competencias básicas en libros de texto de historia y en aprendizajes de estudiantes. Did. Ci. Exp. Soc. 27, 43-66. doi: $10.7203 /$ dces. 27.2648

Sáiz, J. (2014). Fuentes históricas y libros de texto en Secundaria: una oportunidad perdida para enseñar competencias de pensamiento histórico. Ensayos 29, 83-99. doi: 10.18239/ensayos.v29i1.503

Sáiz, J., and López-Facal, R. (2015). Competencias y narrativas históricas: el pensamiento histórico de estudiantes y futuros profesores españoles de Educación Secundaria. Rev. Est. Soc. 52, 87-101. doi: 10.7440/res52.2015.06

Sandwell, R., and Von Heyking, A. (2014). Becoming a history teacher: Sustaining practices in historical thinking and knowing. Toronto: University of Toronto Press.

Schmidt, M. A., and Fronza, M. (2018). Jovens, consciência histórica e avaliação da aprendizagem: o caso do Exame Nacional do Ensino Médio no Brasil entre 2009/2015. Educatio Siglo XXI 36, 149-171. doi: 10.6018/j/324211

Seixas, P. (1993). The community of inquiry as a basic for knowledge and learning: the case of history. Am. Educ. Res. J. 30, 305-324. doi: 10.2307/1163237

Seixas, P. (ed.) (2004). Theorizing historical consciousness. Toronto: University of Toronto Press.

Seixas, P. (2017). "Historical consciousness and historical thinking" in Palgrave handbook of research in historical culture and education. eds. M. Carretero, S. Berger and M. Grever (London: Palgrave Macmillan), 59-72.

Seixas, P., and Morton, T. (2013). The big six historical thinking concepts. Toronto: Nelson Education.

Solé, G. (2014). O manual escolar no ensino primário em Portugal: perspectiva histórica e análise do ensino da História através deste recurso didático. Ensayos 29, 43-64. doi: 10.5944/hme.6.2017.17128

Solé, G. (2018). "A História nos manuais escolares de 1. Ciclo do Ensino Básico: umestudo longitudinal a partir dos manuais de 4. ano de Estudo do Meio" in O Manual Escolar no Ensino da História: Visões Historiográficas. eds. O. G. Solé and I. Barca (Lisbon: Associação de Professores de História), $321-350$.

Solé, G. (2019). Children's understanding of time: a study in a primary history classroom 1. Hist. Educ. Res. J. 16, 158-173. doi: 10.18546/HERJ.16.1.13

Solé, G., and Barca, I. (2018). O Manual Escolar no Ensino da História: Visões Historiográficas e Didática. Lisbon: Associação de Professores de História. Available at: https://aph.pt/o-manual-escolar-no-ensino-da-historia-visoeshistoriograficas-e-didaticas/ (Accessed July 7, 2019).

Stearns, P. N., Seixas, P., and Wineburg, S. (2000). Knowing, teaching, and learning history: National and international perspectives. New York: New York University Press.

Trepat, C. A. (2011). "Concepto y técnicas de evaluación de las ciencias sociales" in Didáctica de la Geografía e la Historia. ed. C. J. Prats (Madrid: Ministerio de Educación, Cultura y Deporte), 199-222.

Valls, R. (2001). Los estudios sobre manuales escolares de historia y sus nuevas perspectivas. Di. Ci. Exp. Soc. 15, 23-36.

Valls, R. (2007). Historiografía escolar española: siglos XIX-XXI. Madrid: UNED.

Valls, R. (2008). La enseñanza de la Historia y textos escolares. Buenos Aires: Zorzal.

Valls, R., and Colomer, J. C. (2018). "El modelo de historias generales" in Repensamos la geografía e historia para la educación democrática. eds. C. V. Peris, D. Parra and X. M. Souto (Valencia: Nau llibres), 23-36.

Van Nieuwenhuyse, K. (2016). Reasoning with and/or about sources on the cold war? The use of primary sources in English and French history textbooks for upper secondary education. Int. J. Hist. Soc. Sci. Educ. 1, 19-51.

Van Sledright, B. A. (2011). The challenge of rethinking history education. On practices, theories, and policy. New York: Routledge.

Van Sledright, B. A. (2014). Assessing historical thinking and understanding. New York/London: Routledge.

Vidal-Abarca, E. (2010). "El contenido y la evaluación de los aprendizajes" in Aprendizaje y desarrollo de la personalidad. eds. E. Vidal-Abarca, R. García and F. Pérez (Madrid: Alianza), 99-138.

Viñao, A. (2003). La educación en valores y los libros de texto. Ceapa 76, $20-22$.

Virranmäki, E., Valta-Hulkkonen, K., and Pellikka, A. (2020). Geography tests in the Finnish matriculation examination in paper and digital forms - an analysis of questions based on revised Bloom's taxonomy. Stud. Educ. Eval. 66, 1-13. doi: 10.1016/j.stueduc.2020.100896

Wineburg, S. (1991). On the reading of historical texts: notes on the breach between school and academy. Am. Educ. Res. J. 28, 495-519. doi: $10.2307 / 1163146$

Wineburg, S. (2001). Historical thinking and the other unnatural acts: Charting the future of teaching the past (critical perspectives on the past). Philadelphia: Temple University Press.

Wineburg, S., Martin, D., and Monte-Sano, C. (2013). Reading like a historian. Teaching literacy in middle and high school history classrooms. New York: Teachers C.

Zachos, D., and Michailidou, A. (2014). "Others," in textbooks: the case of Greek sixth Grade's history textbook. Theory Act. 7, 1-25. doi: 10.3798/ tia.1937-0237.14016

Zanazanian, P. (2015). Historical consciousness and metaphor: charting new directions for grasping human historical sense-making patterns for knowing and acting in time. Hist. Enc. J. 2, 16-33.

Conflict of Interest: The authors declare that the research was conducted in the absence of any commercial or financial relationships that could be construed as a potential conflict of interest.

Copyright () 2020 Gómez, Solé, Miralles and Sánchez. This is an open-access article distributed under the terms of the Creative Commons Attribution License (CC BY). The use, distribution or reproduction in other forums is permitted, provided the original author(s) and the copyright owner(s) are credited and that the original publication in this journal is cited, in accordance with accepted academic practice. No use, distribution or reproduction is permitted which does not comply with these terms. 